\title{
ReSEARChArticle
}

\section{Influence of nitrogenous fertilizer levels, planting density and IDM on severity of sheath blight of rice caused by Rhizoctonia solani Kuhn in northern Karnataka}

\author{
P. Nagaraju and M.K. Naik
}

\begin{abstract}
SUMMARY
The study was conducted to know the influence of nitrogenous fertilizer levels, planting density and integrated disease management (IDM) on the severity of sheath blight of rice in northern Karnataka. The results indicated that, application of $200 \mathrm{~kg} \mathrm{~N}$ per ha recorded higher per cent disease index (PDI) of 40.37 per cent. However, increased N application from $100 \mathrm{~kg} \mathrm{~N}$ to $350 \mathrm{~kg} \mathrm{~N}$ per ha resulted in increased PDI from 17.04 to $62.60 \%$, respectively. Minimum PDI (23.33\%) and higher grain yield $(67.80 \mathrm{~g} / \mathrm{ha}$ ) were recorded at $150 \mathrm{~kg} \mathrm{~N}$ per ha which is the recommended $\mathrm{N}$ dosage in Thunga Bhadra Project command area of Karnataka state. Among different planting densities, the system of rice intensification (SRI) method $\left(16\right.$ hills $\left./ \mathrm{m}^{2}\right)$ recorded least PDI $(5.00 \%)$ and highest grain yield $(67.16 \mathrm{q} / \mathrm{ha})$ whereas increased planting density from 20 to 70 hills per $\mathrm{m}^{2}$ resulted in higher PDI from 6.86 to 45.18 per cent, respectively. However, at 50 hills per $\mathrm{m}^{2}, 16.12$ PDI was recorded with a grain yield of 60.53 q per ha which is the recommended planting density. In the integrated disease management (IDM) trial, wherein, use of cultivar, IR-64 (moderately resistant variety) with foliar application of fungicide hexaconazole (@0.1\%) resulted in minimum PDI of $21.26 \%$ with higher grain yield of $71.74 \mathrm{q}$ per ha as against 34.73 PDI and 56.87 q per ha grain yield in Samba mahsuri (susceptible variety).
\end{abstract}

Key Words : Nitrogen fertilizer, Planting density, IDM, Sheath blight, Rice

How to cite this article : Nagaraju, P. and Naik, M.K. (2018). Influence of nitrogenous fertilizer levels, planting density and IDM on severity of sheath blight of rice caused by Rhizoctonia solani Kuhn in northern Karnataka. Internat. J. Plant Sci., 13 (1): 7-11, DOI: 10.15740/HAS/IJPS/13.1/7-11.

Article chronicle : Received : 21.07.2017; Revised : 03.11.2017; Accepted : 17.11.2017

\section{MEMBERS OF THE RESEARCH FORUM}

Author to be contacted :

P. Nagaraju, AICRP on Groundnut, University of Agricultural Sciences, Dharwad (Karnataka) India

Email : nagarajup66@gmail.com; nagarajup10209@uasd.in

Address of the Co-authors:

M.K. Naik, Department of Plant Pathology, University of Agricultural Sciences, Raichur (Karnataka) India 